\title{
Article \\ Decoupling Analysis between Rural Population Change and Rural Construction Land Changes in China
}

\author{
Xueru Zhang ${ }^{1}$, Jie Wang ${ }^{1}$, Wei Song ${ }^{2, *}$, Fengfei Wang ${ }^{1}$, Xing Gao ${ }^{1}$, Lei Liu ${ }^{1}$, Kun Dong ${ }^{1}$ and Dazhi Yang ${ }^{2,3}$ \\ 1 School of Public Administration, Hebei University of Economics and Business, Shijiazhuang 050061, China; \\ zhangxueru5@pku.edu.cn (X.Z.); xp127970@heuet.edu.cn (J.W.); dangwu5600@heuet.edu.cn (F.W.); \\ gaoxing@heuet.edu.cn (X.G.); hbjml1402@heuet.edu.cn (L.L.); dongkun1113@heuet.edu.cn (K.D.) \\ 2 Key Laboratory of Land Surface Pattern and Simulation, Institute of Geographic Sciences and Natural \\ Resources Research, Chinese Academy of Sciences, Beijing 100101, China; yangdazhi@igsnrr.ac.cn \\ 3 College of Resources and Environment, University of Chinese Academy of Sciences, Beijing 100049, China \\ * Correspondence: songw@igsnrr.ac.cn
}

check for updates

Citation: Zhang, X.; Wang, J.; Song, W.; Wang, F.; Gao, X.; Liu, L.; Dong, K.; Yang, D. Decoupling Analysis between Rural Population Change and Rural Construction Land Changes in China. Land 2022, 11, 231 https://doi.org/10.3390/land11020231

Academic Editor: Carlos Parra-López

Received: 18 December 2021

Accepted: 29 January 2022

Published: 4 February 2022

Publisher's Note: MDPI stays neutral with regard to jurisdictional claims in published maps and institutional affiliations.

Copyright: (C) 2022 by the authors. Licensee MDPI, Basel, Switzerland. This article is an open access article distributed under the terms and conditions of the Creative Commons Attribution (CC BY) license (https:/ / creativecommons.org/licenses/by/ $4.0 /)$.

\begin{abstract}
Developing countries account for about $86.5 \%$ of the world's population and are experiencing rapid urbanization. Globally, the increase in the urban population is generally accompanied by the expansion of the latter and construction lands, as well as the reduction in the rural population and rural construction lands. However, with the rapid development of urbanization in China, the rural population has decreased, while the proportion of rural construction lands has increased, resulting in a significant waste of land resources. In order to quantitatively characterize the degree of deviation between the permanent rural population and rural construction lands based on the 2009-2016 demographic data and land survey data in China, we comprehensively used the decoupling model and the coordination degree model to analyze the temporal change characteristics, spatial distribution law, and the degree of deviation of rural construction land areas and the number of rural permanent residents. Firstly, according to the decoupling model, the type of decoupling between the area of rural construction lands and the number of rural permanent residents at the national scale was strongly negative. Secondly, according to the coordination degree model, the coordination type between rural construction land areas and the rural resident population was uncoordinated; at the provincial scale, the coordination system involved one city and one district (Beijing and the Tibet Autonomous Region) and the basic coordination of two cities (Tianjin and Shanghai). Xinjiang and Qinghai belonged to the reconcilable type, and the other 25 provinces belonged to the uncoordinated type. Finally, according to the comprehensive measurement model, the number of rural permanent residents and rural construction lands showed two types of decoupling: highly strong negative decoupling incoordination and moderately and weakly strong negative decoupling incoordination.
\end{abstract}

Keywords: land use; rural construction land; rural permanent population; decoupling; China

\section{Introduction}

Between 1950 and 2015, the urbanization rate of less-developed countries and regions increased from 17.7 to $49.0 \%$. Among them, China had made the greatest contribution to the increase in urbanization, and therefore China's urbanization had actually become an important factor affecting the world's population and economic development [1]. From 1978 to 2018, the number of cities in China increased from 193 to 657, and the urbanization rate increased from 17.9 to $58.5 \%$ [2]. Urbanization has played an important role in promoting economic development and social progress. Urbanization has also transformed much of the rural population into urban residents [3,4], delivering huge social benefits. Globally, the increase in the urban population is generally accompanied by the expansion of the latter and construction lands, as well as the reduction in the rural population and rural construction lands. However, China's rural construction land areas have not decreased with the transfer of the rural permanent resident population, and the phenomenon of 
"increasing construction lands with people leaving" has even emerged [5,6], resulting in a significant waste of land resources. Indeed, there is a severe imbalance between rural construction lands and the rural resident population.

Therefore, this study was based on geographic information system (GIS) technology and the application of quantitative analyses of decoupling and coordination models to analyze the decoupling degree of rural construction land scales and population scales. Then, we verified and supplemented the research content of rural human and local relations and enriched the research methods of rural human-land relations. Specifically, the research objectives of this article were to: (1) reveal the temporal change characteristics of rural construction lands and the rural population and (2) evaluate the coupling relationship between the rural construction lands and the rural population change in China and analyze the spatial distribution laws and degree of divergence between the two. In the second part, the related research progress of rural hollow villages is combed. The research status of rural population outflow in the process of urbanization is reviewed. The progress and shortcomings of current research are comprehensively analyzed. In the third part, the source of data used in this study is explained, and the coupling model and co-scheduling are introduced. In the fourth part, it analyzes the temporal and spatial changes of rural construction land and the resident population in China and expounds the deviation degree of rural construction land and the resident population in China under the decoupling model, the coordination model, and the comprehensive model. The fifth part mainly discusses the limitations of this study and the next research direction. The sixth part is the main conclusions of the study.

This study reveals the dynamic relationship between permanent residents and construction lands in rural areas of China and quantitatively measured the degree of deviation between them, which is conducive to providing a scientific basis for scientifically formulating land-management policies. At the same time, China is the largest developing country in the world at present. Actively exploring the land-population problem in China's rural areas at this stage and identifying solutions can also provide valuable insights for other developing countries aiming to solve similar problems.

\section{Literature Review}

\subsection{Research Progress of Rural Hollowing}

Due to changes in population, the economy, and policies, China's land-use/landcover change (LUCC) has also undergone a series of complex processes [7-9]. In recent years, research on the changing use of rural construction lands has attracted increasing attention from scholars, especially regarding the rural hollowing-out phenomenon. At present, research considering the hollow villages in China mainly focuses on their formation mechanisms [10-13], influencing factors [14-17], driving-force mechanisms [11,13,18], degree measurements [19-21], and comprehensive land remediation [22-24]. For example, Wang et al. [11] believed that traditional hollowing in rural areas was mainly formed by a combination of land, population, and industry. Li and $\mathrm{Wu}$ [18] believed that hollow villages were driven by complex processes under different spatial conditions with different sensitivities to geography, economy, resources, transportation, population, and geological factors. Liu et al. [25] also explained the forms and causes of rural hollowing-out, stating that the hollowing-out process was not only driven by internal forces but also aggravated by external institutional obstacles during the evolution process. Delfmann et al. [26] believed that the rapid development of cities and the improvement in people's living standards had prompted more of the rural population to move to cities. Through the investigation of farmers, $\mathrm{Yu}$ [27] found that the average homestead hollowing rate in China reached 10.2\%, among which, North China, East China, and Central China had high rural hollowing rates, while the homestead hollowing rates in the northwest and southwest were low. In addition, Li et al. [28] used Dancheng County in the hinterland of the Huanghuaihai Plain as a case study and proposed that community-based rural residential land consolidation and allocation (RRLCA) would help revitalize hollow villages. At present, a large number of 
scholars have used examples to study the reasons, processes, results, and coping strategies of hollowing-out in rural China.

\subsection{Research Status of Rural Population Outflow}

The decoupling model comes from the field of physics, which means that the response relationship between two or more physical quantities with corresponding relationships does not exist, and it has been widely used in the fields of agriculture, resources, and environment, etc. Song et al. [29] used this model to evaluate the decoupling status and the dynamic trend of China's provincial carbon-dioxide emissions; Wang et al. [30] used this model to explore the driving factors of decoupling economic growth from carbon emissions; Wu et al. [31] used this model to study the comparative study of economic growth and carbon emissions between developing countries and developed countries. Over the past decades, the rapid process of urbanization worldwide has driven population migration $[32,33]$. Scholars' studies of rural population migration have mainly involved investigating the current situation of migration [34,35], evolutionary characteristics [36,37], and influencing factors [38-41]. For example, Su et al. [42] acquired data from the China National Bureau of Statistics and adopted the 1\% sampling survey method, reaching the conclusion that the scale of the Chinese rural population migration was gradually increasing, and the proportion of migrant workers moving to the east continued to decline; on the other hand, the proportion of migrants flowing to the central and western regions during the same period had been rising. Liu et al. [34] found that the rural population in China began to decrease after 1995, and the decline in most provinces accelerated. Bairoliya and Miller [38] identified social security as an important factor affecting the outward migration of the rural population. In turn, Zhu et al. Zhu [41] used econometric models to demonstrate the significant impact of the income gap on the migration decisions of the rural population. Some scholars have also considered the links between the rural population and settlements in their research works. Qu, et al. [43] used classical elastic coefficient models and spatial statistics to perform effect analyses on population decline and land expansion (PDLE) and explained their results in combination with the theory of human-ground interactions. Yanbo et al. [6] identified the non-synchronicity of rural human-land change rates by measuring the coupling relationship between demographic data and land-use-change survey data in Shandong Province using an elastic coefficient model.

\subsection{Literature Summary}

In general, scholars have achieved relatively satisfactory results on observing the changes in rural construction lands and population; however, these research methods have mostly used classic models for qualitative analyses, lacking supporting research on other quantitative models, and the research work carried out on a national scale was additionally relatively low. It has thus been difficult to fully reveal the relationship between China's rural construction lands and rural population changes.

\section{Data and Methods}

\subsection{Data Sources}

Rural permanent population data and rural construction land area statistics were used in the study. The rural permanent population data were obtained from the China Population and Employment Statistics Yearbook (2009-2016) [44]. The data of rural construction land areas comes from the Land Survey Results Sharing Application Service Platform [45] issued by the Ministry of Natural Resources of the People's Republic of China.

\subsection{Research Methods}

\subsubsection{Decoupling Model}

Based on the decoupling theory, this study used the decoupling-index calculation model and the decoupling-coefficient definition table divided by Tapio [46] to construct a 
decoupling model represented by the ratio between the average annual growth rate of rural construction lands and the average annual growth rate of the rural permanent resident population. The change relationship between the rural construction land areas and the number of rural permanent residents from 2009 to 2016 was then analyzed. The decoupling coefficient was used to reflect whether the rural construction lands met the rural permanent population's transformation. The formula is as follows:

$$
\alpha_{(\mathrm{n}+1)}=\frac{\left(\mathrm{L}_{(\mathrm{n}+1)}-\mathrm{L}_{\mathrm{n}}\right) / \mathrm{L}_{\mathrm{n}}}{\left(\mathrm{P}_{(\mathrm{n}+1)}-\mathrm{P}_{\mathrm{n}}\right) / \mathrm{P}_{\mathrm{n}}}
$$

where $\mathrm{n}$ is the $\mathrm{nth}$ year; $\mathrm{n}+1$ is the decoupling coefficient in the $\mathrm{n}+1$ year; $\mathrm{L}_{(\mathrm{n}+1)}$ is the area of rural construction lands in the $n+1$ year; $L n$ is the area of rural construction lands in the $n$ year; $P_{(n+1)}$ is the number of rural permanent residents in the $n+1$ year; and $P_{n}$ is the number of rural permanent residents in the nth year.

According to the studies of Li et al. [47] and Tapio [46], decoupling-system values of 0.8 and 1.2 could be used as the basis for dividing the decoupling states, and the evolution characteristics of the supply and demand of rural construction lands could be divided into eight categories (Table 1):

(1) Strong decoupling referring to the growth of the rural permanent population with reduced rural construction lands;

(2) Weak decoupling, meaning that both the number of rural permanent residents and the area of rural construction lands were increasing, and the growth rate of rural construction lands was lower than that of the rural permanent population;

(3) Expansion link referring to a similar increase in the area of rural construction lands and the number of the rural permanent population;

(4) Negative expansion decoupling, meaning that both the rural construction land areas and the rural permanent population were increasing, and the growth rate of the rural construction land areas was faster than that of the rural permanent population;

(5) Strong negative decoupling referring to a decrease in the permanent population in rural areas and an increase in the area of rural construction lands;

(6) Weak negative decoupling meaning that both the number of rural permanent residents and the area of rural construction lands were decreasing, and the rate of decrease of rural construction lands was slower than that of the rural permanent residents;

(7) Recession link referring to the rural construction land areas and the rural permanent resident population being reduced to a similar extent;

(8) Recession decoupling, meaning that the number of the rural permanent resident population and the area of rural construction lands were decreasing, and the reduction rate of the rural construction land areas was faster than that of the population. The decoupling classification is shown in the following table:

Table 1. Definition of the decoupling coefficient.

\begin{tabular}{|c|c|c|c|c|}
\hline \multicolumn{2}{|c|}{ Decoupling State } & RL & RP & $\alpha$ \\
\hline \multirow{3}{*}{ Negative decoupling } & Expanding negative decoupling & $>0$ & $>0$ & $>1.2$ \\
\hline & Strong negative decoupling & $>0$ & $<0$ & $<0$ \\
\hline & Weak negative decoupling & $<0$ & $<0$ & $0<\alpha<0.8$ \\
\hline \multirow{3}{*}{ Decoupling } & Weak decoupling & $>0$ & $>0$ & $0<\alpha<0.8$ \\
\hline & Strong decoupling & $<0$ & $>0$ & $<0$ \\
\hline & Recession decoupling & $<0$ & $<0$ & $>1.2$ \\
\hline \multirow{2}{*}{ Link } & Expansion link & $>0$ & $>0$ & $0.8<\alpha<1.2$ \\
\hline & Recession link & $<0$ & $<0$ & $0.8<\alpha<1.2$ \\
\hline
\end{tabular}




\subsubsection{Coordination Degree Model}

The coordination degree model was used to reflect the degree of coordination within the system, reflecting the trend from disorder to order. The degree of coordination between rural construction lands and the rural resident population is an index to measure the degree of coordination between them. This study introduced a coordination model to analyze the coordination between the national rural construction lands and the rural permanent resident population. The coordination model [48] is as follows:

$$
C_{x y}=(x+y) / \sqrt{x^{2}+y^{2}}
$$

where $\mathrm{x}$ is the average annual change rate of the rural construction land areas; $\mathrm{y}$ is the average annual change rate of the rural permanent resident population; and $C_{x y}$ is the coordination degree of rural construction lands and the rural permanent resident population. The $C_{x y}$ is between the values of -1.414 and 1.414. The type of coordination degree between the rural construction lands and the permanent resident population is shown in the Table 2 below.

Table 2. Definition of coordination degree.

\begin{tabular}{ccc}
\hline $\mathrm{C}_{\mathrm{xy}}$ & $\mathrm{x}, \mathrm{y}$ & Coordination Degree Type \\
\hline $\mathrm{C}_{\mathrm{xy}}=1.414$ & $\mathrm{x}=\mathrm{y}$, and $\mathrm{x}>0, \mathrm{y}>0$ & More coordinated \\
$1.2 \leq \mathrm{C}_{\mathrm{xy}}<1.414$ & $\mathrm{x} \approx \mathrm{y}$ & Coordinated \\
$1.0 \leq \mathrm{C}_{\mathrm{xy}}<1.2$ & $\mathrm{x}>0, \mathrm{y}>0$ and $\mathrm{x}>\mathrm{y}$ & Basically coordinated \\
$0.5 \leq \mathrm{C}_{\mathrm{xy}}<1.0$ & $\mathrm{x}>0, \mathrm{y}<0$ & Reconcilable \\
$-1.414 \leq \mathrm{C}_{\mathrm{xy}}<0$ & $\mathrm{x}<0, \mathrm{y}<0$, or $\mathrm{x}>0$, and $\mathrm{y}<0$ & Uncoordinated \\
\hline
\end{tabular}

\section{Results and Analysis}

\subsection{Temporal Change in the Rural Permanent Population and Lands from 2009 to 2016}

From 2009 to 2016, the number of permanent residents in rural areas continued to decrease (Figure 1). The rural permanent population decreased from 721 million in 2009 to 603 million in 2016, with a total reduction of 118 million people-an average annual decrease of 14.75 million people and an average annual reduction rate of $2.04 \%$. During different periods, the range of changes in the rural permanent population was not the same. From 2009 to 2011, it showed a rapid decline; the rural permanent population decreased by 58.54 million in three years, with an average annual reduction rate of $4.1 \%$. After 2011, the reduction rate of the rural permanent population decreased, and the rural permanent population decreased by 10.62 million, with an average annual reduction rate of $1.62 \%$. As the processes of industrialization and urbanization continued to accelerate, urban infrastructures gradually improved, and medical and health standards continued to improve. The agglomeration effect of cities had caused rural labor to flow to big cities. This was an important factor that caused a continuous decline in the number of rural residents.

From 2009 to 2016, the area of rural construction lands continued to increase. The area of rural construction lands increased from 18.4728 million hm${ }^{2}$ in 2009 to 19.2003 million hm² in 2016, with a total increase of $722,500 \mathrm{hm}^{2}$, an average annual increase of $90,300 \mathrm{hm}^{2}$, and an average annual growth rate of $0.55 \%$. The area of rural construction lands was constantly increasing, but the growth rate decreased year by year. From 2009 to 2011, the average annual growth rate of rural construction land areas was $0.61 \%$. From 2012 to 2014 , the average annual growth rate of rural construction land areas was $0.55 \%$, and from 2015 to 2016, it was $0.44 \%$. During the process of rapid urbanization, the influx of the rural population turned into urban areas and turned into the urban population (people living in cities and towns for more than six months each year). However, the areas of rural construction lands did not decrease due to the decrease in the rural population (non-urban resident population) but instead showed an increasing trend. The "separation of people and lands, and the increased use of land for construction with people leaving" in rural 
areas eventually led to the doubled increase in construction lands in both urban and rural areas.

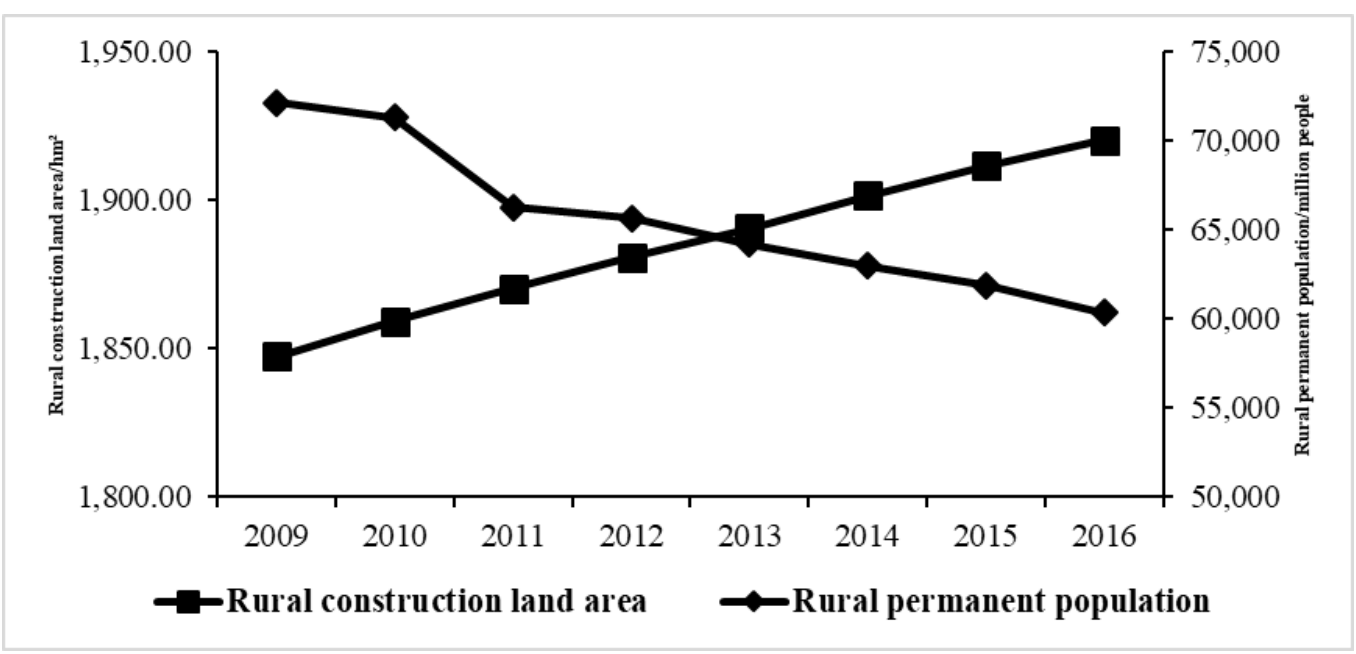

Figure 1. Change trend of the number of the rural permanent population and rural construction land areas from 2009 to 2016.

\subsection{Spatial Changes in the Rural Permanent Population and Lands from 2009-2016}

From 2009-2016, the rural permanent population was declining. Exceptions included Beijing, Tianjin, Shanghai, and Tibet. Figure 2 shows that:

(1) The rural permanent population was severely reduced in the seven provinces of Henan, Jiangsu, Sichuan, Shandong, Guizhou, Anhui, and Hubei. Over the past eight years, the rural permanent population of the seven provinces had decreased by 9.927 , $8.385,8.034,7.016,6.417,6.093$, and 6.046 million, respectively, and the cumulative decrease in the rural permanent population accounted for $44.04 \%$ of the country's total rural permanent population decrease. Most of these seven provinces are located in the central and eastern regions of China, with large populations and a high proportion of rural residents. Rural populations were prominent during the process of rapid urbanization of China.

(2) Areas experiencing a moderate decrease in the number of the rural permanent population included eight provinces, namely, Gansu, Guangxi, Jiangxi, and other provinces. Most of the provinces were relatively backward economically. Most of the rural permanent population decreased by between 3 and 4 million. The average annual reduction rate of the rural permanent population was $2.285 \%$.

(3) The rural permanent population decreased slightly in seven provinces including Liaoning, Zhejiang, Chongqing, Shanxi, Inner Mongolia, Heilongjiang, and Guangdong. The rural resident population has decreased by 14.4014 million in the past eight years.

(4) The slight reduction zone included five provinces, namely, Jilin, Xinjiang, Ningxia, Qinghai, and Hainan. The rural permanent population decreased by 492,000, 412,000, $410,000,353,000$, and 350,800, respectively. The average reduction rate of the rural permanent population in the five provinces was $1.13 \%$. The five provinces developed slowly with low levels of urbanization and small population bases. The rural population of the five provinces occupied a small proportion of the national rural population, and the rural population preferred local employment with a slow population flow.

(5) The rural permanent population growth area was focused on three cities and one region (Shanghai, Beijing, Tianjin, and Tibet). From 2009-2016, the rural permanent population in the four provinces and cities has increased by 837,000, 370,000, 119,000, and 12,000 , respectively. Beijing, Tianjin, and Shanghai are all municipalities that are directly controlled by the Central Government, with a developed economy, a small 
gap between urban and rural areas, and high social welfare in rural areas. In addition, the urbanization rates of the three regions reached $86.5,82.93$, and $87.7 \%$, respectively, in 2017. The levels of urbanization were high, with densely populated urban centers, high housing prices, and traffic congestion. By then, "counter-urbanization" had begun to appear, and the population had shifted to urban suburbs or rural areas. According to the provincial administrative region analysis, the urbanization rate of the Tibet Autonomous Region was only 30.9\%, with slow urbanization rates and a weak effect on rural population transfer. Indeed, a large number of people still lived in rural areas. From 2009-2016, the annual growth rate of the rural permanent population has been $0.75 \%$. In 2017 , the natural population growth rate reached $1.1 \%$, and the natural population growth rate was high. Eventually, the rural permanent population in Tibet's rural areas did not decrease but increased instead.

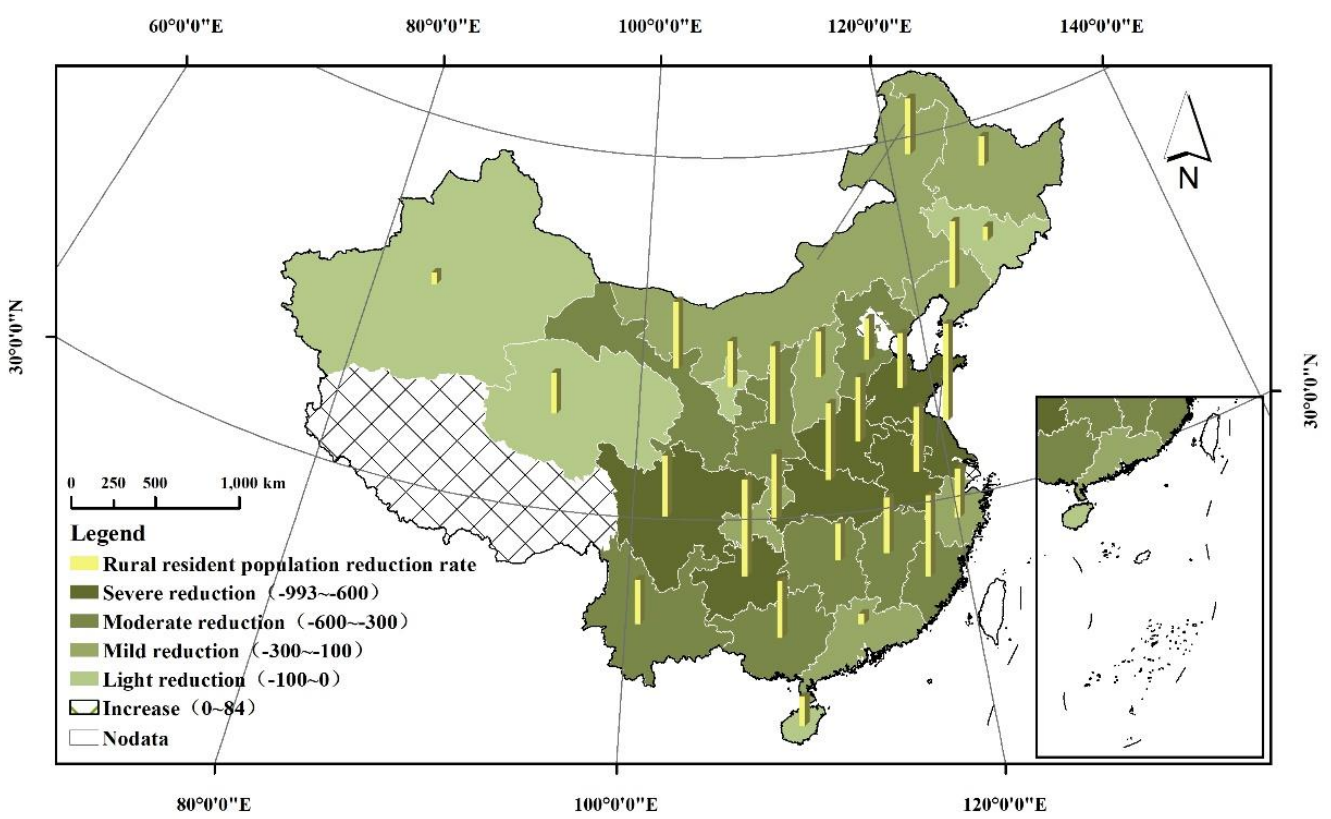

Figure 2. Spatial pattern of the absolute increase and average annual reduction rate of the rural permanent population from 2009 to 2016.

From 2009 to 2016, the area of rural construction lands in most provinces in China increased. The increase in rural construction land areas varied between different provinces. As shown in the Figure 3:

(1) The areas experiencing a severe increase in rural construction lands were Xinjiang, Hebei, Shandong, and Zhejiang. During this period, the areas of rural construction lands increased by $162.9 \mathrm{hm}^{2}, 154.8 \mathrm{hm}^{2}, 129.7 \mathrm{hm}^{2}$, and $93.5 \mathrm{hm}^{2}$, respectively. The increase in rural construction land areas in the four provinces over the past eight years accounted for $49.56 \%$ of the total increase in rural construction lands in the country. From 2009 to 2016 , the annual growth rate of rural construction land areas was $0.55 \%$, and the annual growth rates of rural construction lands in the four provinces exhibiting great increments of these areas were $2.55,1.21,0.9$, and $1.78 \%$, far exceeding the national average. In addition, the increase in rural construction lands occurred rapidly.

(2) Most of the moderately increasing areas with increasing rural construction land areas were located in the southeast coastal and central and western regions, including eight provinces such as Guangdong, Fujian, Jiangsu, Inner Mongolia Gansu, etc. The average annual growth rate of rural construction lands was between 0.31 and $1.03 \%$. Among them, the annual growth rate of rural construction lands in Fujian reached 1.03\%, which was twice that of the annual growth rate of China. Although the increase was small, the growth rate 
was faster. Attention should thus be paid to strengthening the economical and intensive use of rural lands.

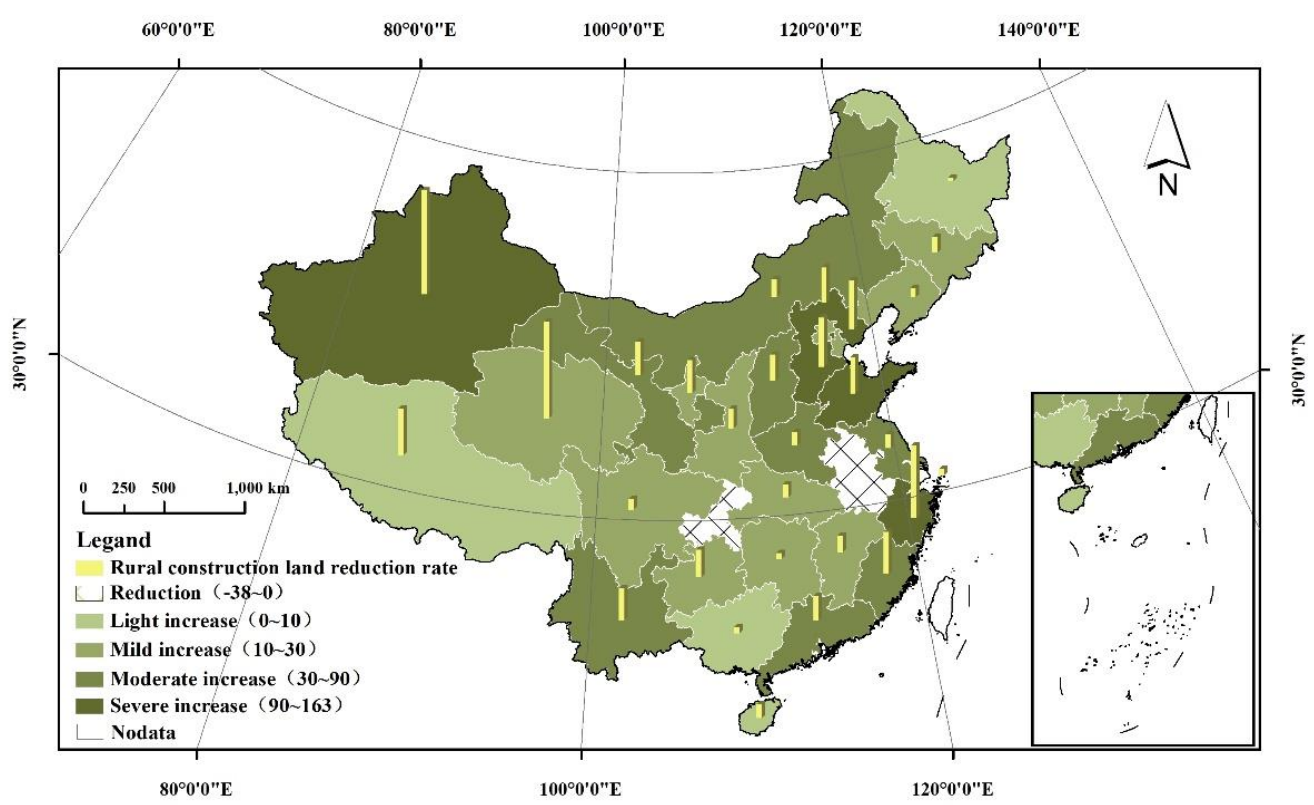

Figure 3. Space pattern of the absolute increase and average annual growth rate of rural construction land areas from 2009-2016.

(3) The mildly increasing areas of rural construction lands were mainly located in the western, central, and northeast regions, including twelve provinces, such as Gansu, Sichuan, Guizhou, Hubei, Hunan, Jilin, Liaoning, etc. The mildly increasing areas accounted for $22.03 \%$ of the national increase in rural construction lands.

(4) Areas with lightly increasing rural construction lands included Guangxi, Tibet, Heilongjiang, and Hainan. The increase in rural construction land areas was between $4.3 \mathrm{hm}^{2}$ and $9.1 \mathrm{hm}^{2}$, with average annual growth rates of $0.16,1.16,0.07$, and $0.34 \%$, respectively. It can be seen that the growth rate of rural construction land areas in Tibet was much higher than that of the other three provinces. The main reason was that Tibet is vast and sparse but nonetheless underwent rapid economic development. In 2016, the per capita disposable income of rural residents reached CNY 9094, with farmers' living standards improving and new rural construction gradually accelerating.

(5) In rural construction land-reduction areas including Chongqing and Anhui, the rural construction land proportions have decreased by $11.7 \mathrm{hm}^{2}$ and $37.6 \mathrm{hm}^{2}$, respectively, over the past eight years, with an average annual reduction rate of $1.11 \%$. On the one hand, during the process of China's urban and rural transformation, a large number of rural labor forces flowed into cities and towns, promoting the improvement in urbanization, and the large number of rural inhabitants exiting these areas led to a continuous reduction in the rural permanent population. However, the rural construction lands were inadequately adjusted according to the planning expectations. On the other hand, due to the new demand for construction lands generated by rural renewal, it did not make full use of the idle homestead but occupied a large amount of cultivated land. The idle use of the original homestead and the new demand for construction lands had indeed caused the continuous expansion of rural construction lands alongside a phenomenon of serious land-population incoordination.

\subsection{Coupled Type of Rural Construction Land Area and the Number of the Rural Permanent Population from 2009 to 2016}

To accurately grasp the rural "person-land" relationship, we constructed a decoupling model and coordination model between the areas of rural construction lands and the size 
of the rural permanent population. By analyzing the results of the two models, we were able to more adequately reflect the coupling relationship between them. According to the decoupling and coordination models, the decoupling coefficient and the coordination degree between the national rural construction lands from 2009 to 2016 and the permanent resident population were calculated, as shown in the table below:

According to the decoupling model, the decoupling relationship between rural construction lands and the rural permanent population changes from 2009 to 2016 showed four states: weak decoupling, negative expansion decoupling, strong negative decoupling, and weak negative decoupling. From 2009 to 2016, the decoupling coefficient of the rural permanent population and rural construction lands was -0.22 (Table 3), which belonged to the class of strong negative decoupling, indicating that the rural permanent population was decreasing, and the decreasing rate was higher than that of rural construction lands. At the provincial scale, Beijing and Shanghai exhibited weak decoupling. Beijing and Shanghai each have a developed economy, a small urban-rural gap, high rural social-welfare levels, and relatively high employment rates even in rural areas. In addition, the two cities have high levels of urbanization, a dense population, traffic congestion, and high housing prices. The phenomenon of "counter-urbanization" had thus emerged. Some urban residents had migrated to the surrounding suburbs and villages to settle. Tibet and Tianjin encouraged negative expansion decoupling; indeed, both the rural permanent population and rural construction lands were increasing, and the growth rate of rural construction lands was greater than that of the rural permanent population. Chongqing and Anhui belonged to the class having underwent weak negative decoupling. The uncoordinated type of the two provinces was different from that of other provinces. In this region, both the rural resident population and the rural construction lands had a decreasing trend, but the decreasing rate of the rural resident population was greater than that of the rural construction lands. Strong negative decoupling areas were observed in 25 provinces, including Hebei, Shanxi, Inner Mongolia, and Liaoning, etc. In short, the coordinated areas of rural construction lands and the rural permanent population in 25 provinces exhibited strongly negative decoupling to different degrees; in fact, in the case of the rapid reduction in the rural permanent resident population, the areas of rural construction land were not reduced but increased instead, resulting in a significant waste of construction land resources.

Table 3. The decoupling coefficient and coordination degree between rural construction lands and the rural permanent population.

\begin{tabular}{|c|c|c|c|c|c|c|c|}
\hline Province & $\begin{array}{c}\text { Rural } \\
\text { Permanent } \\
\text { Population } \\
\text { Growth Rate (\%) }\end{array}$ & $\begin{array}{c}\text { Growth Rate of } \\
\text { Rural } \\
\text { Construction } \\
\text { Land }(\%)\end{array}$ & $\begin{array}{l}\text { Decoupling } \\
\text { Coefficient }\end{array}$ & $\begin{array}{c}\text { Type of } \\
\text { Decoupling }\end{array}$ & $\begin{array}{c}\text { Coordination } \\
\text { Degree Cxy }\end{array}$ & $\begin{array}{c}\text { Type of } \\
\text { Coordination }\end{array}$ & $\begin{array}{c}\text { Comprehensive } \\
\text { Type }\end{array}$ \\
\hline Beijing & 1.950 & 0.857 & 0.439 & $\begin{array}{c}\text { Weak } \\
\text { decoupling }\end{array}$ & 1.318 & $\begin{array}{c}\text { More } \\
\text { coordinated }\end{array}$ & $\begin{array}{c}\text { Weak } \\
\text { decoupling and } \\
\text { more } \\
\text { coordinated } \\
\text { Negative }\end{array}$ \\
\hline Xizang & 0.748 & 1.157 & 1.548 & $\begin{array}{l}\text { Expansion } \\
\text { negative } \\
\text { decoupling }\end{array}$ & 1.383 & $\begin{array}{c}\text { More } \\
\text { coordinated }\end{array}$ & $\begin{array}{c}\text { decoupling of } \\
\text { expansion and } \\
\text { more } \\
\text { coordinated }\end{array}$ \\
\hline Tianjin & 0.065 & 1.185 & 18.165 & $\begin{array}{l}\text { Expansion } \\
\text { negative } \\
\text { decoupling }\end{array}$ & 1.053 & $\begin{array}{l}\text { Basically } \\
\text { coordinated }\end{array}$ & $\begin{array}{l}\text { Negative } \\
\text { decoupling of } \\
\text { expansion and } \\
\text { basically } \\
\text { coordinated }\end{array}$ \\
\hline Shanghai & 4.804 & 0.150 & 0.031 & $\begin{array}{c}\text { Weak } \\
\text { decoupling }\end{array}$ & 1.031 & $\begin{array}{l}\text { Basically } \\
\text { coordinated }\end{array}$ & $\begin{array}{c}\text { Weak } \\
\text { decoupling and } \\
\text { basically } \\
\text { coordinated }\end{array}$ \\
\hline Xinjiang & -0.463 & 2.545 & -5.492 & $\begin{array}{l}\text { Strong and } \\
\text { negative } \\
\text { decoupling }\end{array}$ & 0.805 & Reconcilable & $\begin{array}{l}\text { Strong negative } \\
\text { decoupling and } \\
\text { reconcilable }\end{array}$ \\
\hline Qinghai & -1.617 & 2.360 & -1.460 & $\begin{array}{l}\text { Strong and } \\
\text { negative } \\
\text { decoupling }\end{array}$ & 0.260 & Reconcilable & $\begin{array}{l}\text { Strong negative } \\
\text { decoupling and } \\
\text { reconcilable }\end{array}$ \\
\hline
\end{tabular}


Table 3. Cont.

\begin{tabular}{|c|c|c|c|c|c|c|c|}
\hline Province & $\begin{array}{c}\text { Rural } \\
\text { Permanent } \\
\text { Population } \\
\text { Growth Rate (\%) }\end{array}$ & $\begin{array}{c}\text { Growth Rate of } \\
\text { Rural } \\
\text { Construction } \\
\text { Land (\%) }\end{array}$ & $\begin{array}{l}\text { Decoupling } \\
\text { Coefficient }\end{array}$ & $\begin{array}{c}\text { Type of } \\
\text { Decoupling }\end{array}$ & $\begin{array}{c}\text { Coordination } \\
\text { Degree Cxy }\end{array}$ & $\begin{array}{c}\text { Type of } \\
\text { Coordination }\end{array}$ & $\begin{array}{c}\text { Comprehensive } \\
\text { Type }\end{array}$ \\
\hline Nationwide & -2.517 & 0.553 & -0.220 & $\begin{array}{l}\text { Strong and } \\
\text { negative } \\
\text { decoupling }\end{array}$ & -0.762 & Uncoordinated & $\begin{array}{c}\text { Strong negative } \\
\text { decoupling and } \\
\text { uncoordinated }\end{array}$ \\
\hline Hebei & -1.650 & 1.211 & -0.734 & $\begin{array}{l}\text { Strong and } \\
\text { negative } \\
\text { decoupling }\end{array}$ & -0.215 & Uncoordinated & $\begin{array}{l}\text { Strong negative } \\
\text { decoupling and } \\
\text { uncoordinated }\end{array}$ \\
\hline Shanxi & -1.805 & 0.647 & -0.358 & $\begin{array}{l}\text { Strong and } \\
\text { negative } \\
\text { decoupling }\end{array}$ & -0.604 & Uncoordinated & $\begin{array}{l}\text { Strong negative } \\
\text { decoupling and } \\
\text { uncoordinated }\end{array}$ \\
\hline Inner Mongolia & & & & Strong and & & & Strong negative \\
\hline $\begin{array}{l}\text { Autonomous } \\
\text { Region }\end{array}$ & -2.207 & 0.432 & -0.196 & $\begin{array}{l}\text { negative } \\
\text { decoupling }\end{array}$ & -0.789 & Uncoordinated & $\begin{array}{l}\text { decoupling and } \\
\text { uncoordinated }\end{array}$ \\
\hline Liaoning & -2.624 & 0.239 & -0.091 & $\begin{array}{l}\text { Strong and } \\
\text { negative } \\
\text { decoupling }\end{array}$ & -0.905 & Uncoordinated & $\begin{array}{l}\text { Strong negative } \\
\text { decoupling and } \\
\text { uncoordinated }\end{array}$ \\
\hline Jilin & -0.559 & 0.376 & -0.672 & $\begin{array}{l}\text { Strong and } \\
\text { negative } \\
\text { decoupling }\end{array}$ & -0.273 & Uncoordinated & $\begin{array}{l}\text { Strong negative } \\
\text { decoupling and } \\
\text { uncoordinated }\end{array}$ \\
\hline Heilongjiang & -1.172 & 0.073 & -0.063 & $\begin{array}{l}\text { Strong and } \\
\text { negative } \\
\text { decoupling }\end{array}$ & -0.935 & Uncoordinated & $\begin{array}{l}\text { Strong negative } \\
\text { decoupling and } \\
\text { uncoordinated }\end{array}$ \\
\hline Jiangsu & -3.827 & 0.346 & -0.090 & $\begin{array}{l}\text { Strong and } \\
\text { negative } \\
\text { decoupling }\end{array}$ & -0.906 & Uncoordinated & $\begin{array}{l}\text { Strong negative } \\
\text { decoupling and } \\
\text { uncoordinated }\end{array}$ \\
\hline Zhejiang & -1.930 & 1.780 & -0.922 & $\begin{array}{l}\text { Strong and } \\
\text { negative } \\
\text { decoupling }\end{array}$ & -0.057 & Uncoordinated & $\begin{array}{c}\text { Strong negative } \\
\text { decoupling and } \\
\text { uncoordinated } \\
\text { Weak and }\end{array}$ \\
\hline Anhui & -2.575 & -0.315 & 0.122 & $\begin{array}{l}\text { Weak negative } \\
\text { decoupling }\end{array}$ & -1.114 & Uncoordinated & $\begin{array}{c}\text { negative } \\
\text { decoupling and } \\
\text { incongruous } \\
\text { type }\end{array}$ \\
\hline Fujian & -3.219 & 1.029 & -0.320 & $\begin{array}{l}\text { Strong and } \\
\text { negative } \\
\text { decoupling }\end{array}$ & -0.648 & Uncoordinated & $\begin{array}{l}\text { Strong negative } \\
\text { decoupling and } \\
\text { uncoordinated }\end{array}$ \\
\hline Jiangxi & -2.194 & 0.401 & -0.183 & $\begin{array}{l}\text { Strong and } \\
\text { negative } \\
\text { decoupling }\end{array}$ & -0.804 & Uncoordinated & $\begin{array}{l}\text { Strong negative } \\
\text { decoupling and } \\
\text { uncoordinated }\end{array}$ \\
\hline Shandong & -2.167 & 0.898 & -0.414 & $\begin{array}{l}\text { Strong and } \\
\text { negative } \\
\text { decoupling }\end{array}$ & -0.541 & Uncoordinated & $\begin{array}{l}\text { Strong negative } \\
\text { decoupling and } \\
\text { uncoordinated }\end{array}$ \\
\hline Henan & -2.536 & 0.313 & -0.123 & $\begin{array}{l}\text { Strong and } \\
\text { negative } \\
\text { decoupling }\end{array}$ & -0.870 & Uncoordinated & $\begin{array}{l}\text { Strong negative } \\
\text { decoupling and } \\
\text { uncoordinated }\end{array}$ \\
\hline Hubei & -3.020 & 0.324 & -0.107 & $\begin{array}{l}\text { Strong and } \\
\text { negative } \\
\text { decoupling }\end{array}$ & -0.888 & Uncoordinated & $\begin{array}{l}\text { Strong negative } \\
\text { decoupling and } \\
\text { uncoordinated }\end{array}$ \\
\hline Hunan & -1.455 & 0.146 & -0.100 & $\begin{array}{l}\text { Strong and } \\
\text { negative } \\
\text { decoupling }\end{array}$ & -0.895 & Uncoordinated & $\begin{array}{l}\text { Strong negative } \\
\text { decoupling and } \\
\text { uncoordinated }\end{array}$ \\
\hline Guangdong & -0.418 & 0.598 & -1.431 & $\begin{array}{l}\text { Strong and } \\
\text { negative } \\
\text { decoupling }\end{array}$ & 0.247 & Uncoordinated & $\begin{array}{l}\text { Strong negative } \\
\text { decoupling and } \\
\text { uncoordinated }\end{array}$ \\
\hline Guangxi & -2.254 & 0.156 & -0.069 & $\begin{array}{l}\text { Strong and } \\
\text { negative } \\
\text { decoupling }\end{array}$ & -0.929 & Uncoordinated & $\begin{array}{l}\text { Strong negative } \\
\text { decoupling and } \\
\text { uncoordinated }\end{array}$ \\
\hline Hainan & -1.169 & 0.341 & -0.292 & $\begin{array}{l}\text { Strong and } \\
\text { negative } \\
\text { decoupling }\end{array}$ & -0.680 & Uncoordinated & $\begin{array}{l}\text { Strong negative } \\
\text { decoupling and } \\
\text { uncoordinated }\end{array}$ \\
\hline Chongqing & -2.632 & -0.310 & 0.118 & $\begin{array}{l}\text { Weak negative } \\
\text { decoupling }\end{array}$ & -1.110 & Uncoordinated & $\begin{array}{l}\text { negative } \\
\text { decoupling is } \\
\text { incongruous } \\
\text { type }\end{array}$ \\
\hline Sichuan & -2.422 & 0.265 & -0.109 & $\begin{array}{l}\text { Strong and } \\
\text { negative } \\
\text { decoupling }\end{array}$ & -0.885 & Uncoordinated & $\begin{array}{l}\text { Strong negative } \\
\text { decoupling and } \\
\text { uncoordinated }\end{array}$ \\
\hline Guizhou & -3.820 & 0.680 & -0.178 & $\begin{array}{l}\text { Strong and } \\
\text { negative } \\
\text { decoupling }\end{array}$ & -0.809 & Uncoordinated & $\begin{array}{l}\text { Strong negative } \\
\text { decoupling and } \\
\text { uncoordinated }\end{array}$ \\
\hline Yunnan & -1.765 & 0.785 & -0.444 & $\begin{array}{l}\text { Strong and } \\
\text { negative } \\
\text { decoupling }\end{array}$ & -0.508 & Uncoordinated & $\begin{array}{l}\text { Strong negative } \\
\text { decoupling and } \\
\text { uncoordinated }\end{array}$ \\
\hline
\end{tabular}


Table 3. Cont.

\begin{tabular}{|c|c|c|c|c|c|c|c|}
\hline Province & $\begin{array}{c}\text { Rural } \\
\text { Permanent } \\
\text { Population } \\
\text { Growth Rate (\%) }\end{array}$ & $\begin{array}{c}\text { Growth Rate of } \\
\text { Rural } \\
\text { Construction } \\
\text { Land (\%) }\end{array}$ & $\begin{array}{l}\text { Decoupling } \\
\text { Coefficient }\end{array}$ & $\begin{array}{c}\text { Type of } \\
\text { Decoupling }\end{array}$ & $\begin{array}{c}\text { Coordination } \\
\text { Degree Cxy }\end{array}$ & $\begin{array}{c}\text { Type of } \\
\text { Coordination }\end{array}$ & $\begin{array}{c}\text { Comprehensive } \\
\text { Type }\end{array}$ \\
\hline Shaanxi & -3.094 & 0.476 & -0.154 & $\begin{array}{l}\text { Strong and } \\
\text { negative } \\
\text { decoupling }\end{array}$ & -0.836 & Uncoordinated & $\begin{array}{l}\text { Strong negative } \\
\text { decoupling and } \\
\text { uncoordinated }\end{array}$ \\
\hline Gansu & -2.655 & 0.815 & -0.307 & $\begin{array}{l}\text { Strong and } \\
\text { negative } \\
\text { decoupling }\end{array}$ & -0.662 & Uncoordinated & $\begin{array}{l}\text { Strong negative } \\
\text { decoupling and } \\
\text { uncoordinated }\end{array}$ \\
\hline Ningxia & -1.819 & 0.807 & -0.444 & $\begin{array}{l}\text { Strong and } \\
\text { negative } \\
\text { decoupling }\end{array}$ & -0.509 & Uncoordinated & $\begin{array}{l}\text { Strong negative } \\
\text { decoupling and } \\
\text { uncoordinated }\end{array}$ \\
\hline
\end{tabular}

According to the coordination degree model, the Cxy of the national rural permanent population and rural construction lands was -0.762 . The rural permanent population showed a negative growth trend, and the rural construction land area was growing positively, belonging to the uncoordinated type. Focusing on the provincial level, there were five types of more-coordinated, basically coordinated, reconcilable, reluctantly reconcilable, and non-coordinated areas across the country.

More-coordinated areas included Beijing and Tibet. From 2009 to 2016, the average annual growth rate of rural permanent residents in Beijing was greater than that of rural construction lands, and they all showed a positive growth trend with a coordination degree of 1.31. The average annual growth rate of the rural permanent population in the Tibet Autonomous Region was less than that of the rural construction land areas, which also exhibited a positive growth rate, with a coordination degree of 1.38. Although Beijing and Tibet were almost identical in their coordination degrees, they represented completely different types of area, with a wide gap in their levels of development. The growth rate of Beijing's rural permanent population was 2.6 times that of Tibet, and the average annual growth rate of rural construction lands in Tibet was 1.35 times that of Beijing. Tibet is located on the Qinghai-Tibet Plateau, at high altitudes, with harsh natural conditions, backward economic development, high natural growth rates of the rural population, and a low population mobility, as well as having a rural permanent population, which is increasing year by year. Indeed, Tibet covers a large area with a sparse population, extensive land use, and a large per capita area of rural construction lands. Contrarily, Beijing has a developed economy and a high level of urbanization. The phenomenon of "counter-urbanization" has thus appeared. Indeed, the population has begun to shift to surrounding rural areas, which has led to an increase in rural permanent residents.

Basic coordination areas included Tianjin and Shanghai. The urbanization rate in Shanghai was as high as $87.7 \%$, and the rural permanent resident population base was small. The growth rate of the rural permanent population in Shanghai was as high as $4.804 \%$ with the emergence of the anti-urbanization phenomenon. The growth rate of rural construction lands was only $0.15 \%$. It can be seen that the growth rate of the rural permanent population in Shanghai was much higher than that of rural construction lands. In recent years, the reconstruction of the old city and the development of new areas have led to an increase in the suburban areas and the rural population of Shanghai. The continuous acceleration of suburban and rural constructions, the further optimization of urban layout, and the deepening of industrial restructuring have prompted a large number of residents to move from the central city to the suburban countryside. The permanent resident population from outside Shanghai has usually been concentrated in its suburban areas, leading to the rapid growth of the permanent resident population in Shanghai's rural areas. However, the situation between Tianjin and Shanghai was found to be inconsistent. The average annual growth rate of the permanent rural permanent population in Tianjin was $0.065 \%$, and the growth rate of rural construction lands was $1.185 \%$, which was eight times that of rural construction lands in Shanghai. Tianjin has a high level of urbanization, and the phenomenon of "anti-urbanization" supplements labor and production factors to rural 
areas, promotes the flow of urban and rural factors and resources, and also drives the development of the rural economy. In recent years, primary, secondary, and tertiary industries in Tianjin's rural areas have developed rapidly, and the living standards of farmers have improved. By the end of 2014, the disposable income of rural residents had reached CNY 17,014 , and the per capita consumption had reached CNY 13,739. The development of the secondary and tertiary industries provided employment opportunities for rural residents, most of whom chose local employment. Thus, the rural permanent population increased instead of decreasing. Due to the development of secondary and tertiary industries, the demand for construction lands is stronger, and the rural construction land areas in Tianjin continue to expand.

The reconciliation areas included Xinjiang and Qinghai. Both Xinjiang and Qinghai are located in the western region, with poor natural conditions, large areas with sparse populations, low levels of economic development, and low degrees of modernization. Qinghai's urbanization rate was 53.07\%, and Xinjiang's was 49.38\%. The level of urbanization in the two provinces was relatively low. Compared with the urban population, the rural permanent population base was large. The rural living standard of northwest China was relatively low with the rural population flowing to cities. However, the rural construction land areas did not decrease due to the reduction in the rural population; the growth rate of rural construction lands was also much higher than the reduction rate of the rural permanent population, resulting in the current situation of reconciliation between Xinjiang and Qinghai.

The uncoordinated regions included 25 provinces and autonomous regions, including Hebei, Shanxi, Inner Mongolia, Liaoning, Jilin, and Heilongjiang, etc. These provinces had reduced rural permanent populations and increased rural construction lands, and the reduction rate of the rural permanent population was also higher than the increase rate of rural construction lands. While the rural permanent population was continuing to decrease, the rural homestead had not been effectively used, and the rural construction lands were largely abandoned due to unmanned management, resulting in the uncoordinated phenomenon of "people leaving with increasing construction lands" in rural areas.

Considering the decoupling and coordination degree models comprehensively, we can grasp the coordination of the rural permanent population and construction lands more accurately. This study used the natural breakpoint method to divide the strong negative decoupling and uncoordinated provinces into highly strong negative decoupling uncoordinated and moderate to mildly strong negative decoupling uncoordinated ones to explore the degree of strong negative decoupling in these 23 provinces. The results showed that:

(1) The twelve provinces and autonomous regions of Heilongjiang, Guangxi, Jiangsu, Liaoning, Hunan, Hubei, Sichuan, Henan, Shaanxi, Guizhou, Jiangxi, and Inner Mongolia exhibited a highly strong negative decoupling. The average growth rate of the rural permanent resident population in these provinces was $-2.55 \%$, which was much higher than the national average level of $-1.60 \%$. The considerable loss of the rural permanent population was the main reason for the incoordination between the rural population and the scale of construction lands in these provinces.

(2) The eleven provinces, including Hainan, Gansu, Fujian, Shanxi, Shandong, Ningxia, Yunnan, Zhejiang, Hebei, Jilin, and Guangdong, belonged to the moderate- and mildly strong negative decoupling groups. The average population growth rate of the rural permanent population in these 11 provinces was $-1.47 \%$, which was slightly lower than the national average; the average growth rate of rural construction lands in these was $0.84 \%$ - higher than the national average of $0.67 \%$. The expansion of rural construction lands was the most important reason for the highly strong negative decoupling between the rural population and the scale of construction lands in these provinces. 


\section{Discussion}

\subsection{Comparison of Conclusions of Rural Construction Land and Resident Population Change}

This study tried to use the statistical data of the rural resident population and the construction land at the provincial level to study them. According to the research results, the rural land-population relationship in most provinces in China is not harmonious, which is mainly manifested in that except for some economically developed cities such as Beijing, Tianjin, and Shanghai, the rural resident population in most provinces is decreasing, and the rural construction land is increasing instead of decreasing. Therefore, the level of economic development is an important factor affecting the migration of rural population to cities. M. Arzaghi thinks that income is the main factor that affects American rural residents' going to big cities. Scholars such as Fedova T.G., Medvedev A., Ignatius Ani Madu, Enxiang Cai, David Carr, Maksym Polyakov, and others also believe that economic factors are some of the main factors affecting rural population mobility. This is similar to the research results in this study.

\subsection{Limitations of Research}

\subsubsection{Relative Lag of Research Data}

The research results also provide some basis and thinking for China and other developing countries to formulate land-management policies. However, there are still some shortcomings. First of all, due to the slow update of rural construction land data, the research period can only be selected from 2009 to 2016. Therefore, the research results can not represent the current situation of rural land-population in China but can only be used as a long-term development trend for reference. Therefore, after the relevant data is updated, the analysis and research will be carried out again, trying to interpret the latest land-population status in rural China and strengthening the practical significance of the research results. Secondly, this study focused on describing the potential problems of China's rural land-population relationship and lacked related research on its causes and solutions, which will also be the focus of our next study.

\subsubsection{Relative Lag of Research Data}

Finally, it will be interesting to compare the current situation of rural land-population relationships in countries with different development levels. However, after consulting the relevant literature at home and abroad, we found that most of the research literature on the relationship between rural people and land comes from China. The research literature of foreign scholars on the relationship between people and land in China is relatively scarce, focusing mainly on the single study of rural population loss or the development status of rural construction land.

Yan et al. [49] took Ganyugou village as an example to interpret the motivation and mechanism of functional reconstruction of hollow villages in China from the perspective of urban-rural relations; Sun et al. [50] systematically explained the reasons for the formation of hollow villages and took Yucheng City, Shandong Province as an example, putting forward specific methods of structural adjustment in rural areas in detail. In the aspect of rural population loss, Aileen et al. [51] revealed the importance of rural horizontal migration through the empirical data of 260 immigrant families in three case-study areas (Scotland, Wales, and Northern Ireland) in the UK and compared it with anti-urban migration and migration. Liu et al. [34] analyzed the trend and spatial difference of rural population change and the driving force of this process. It is considered that narrowing the regional development gap is the most effective method to reduce rural population outflow. Ge et al. [52] analyzed the relationship between urban-rural population migration and the evolution of the rural man-land relationship, introduced urban power and rural power in push-pull theory, and established an interactive analysis framework between urban-rural population migration and agricultural transformation. Guo et al. [53] used the population data of China to analyze the spatial pattern of rural population migration and urbanization and their coupling and coordination relationship, and they discussed the reasons of their 
spatial heterogeneity. Qi et al. [35] and others analyzed the spatial pattern and driving factors of rural population migration in China by Moran's I method and the spatial lag regression model based on the data of the sixth census in 2010.

Therefore, it is difficult to compare the research conclusions of this study with those of foreign countries. We will also carry out research step by step, trying to explore the present situation of the rural man-land relationship in different regions and countries, so as to understand the rural development process and the development direction of all countries in the world and to provide the basis for rural land policies and rural population policies of developing countries.

\section{Conclusions}

Based on the comprehensive perspective of the relationship between rural populations and lands, this study used the rural construction land decoupling model and the coordination degree model to analyze the type of relationship between the temporal change characteristics, spatial differentiation and coordination of rural construction land areas, and the number of rural permanent residents at the national and provincial levels. The main conclusions were as follows:

(1) Time-wise, from 2009 to 2016, the rural permanent population continued to decrease, and the area of rural construction lands continued to increase. The rural permanent population decreased from 721 million in 2009 to 603 million in 2016, with a total decrease of 118 million, an annual decrease of 14.75 million, and an annual reduction rate of $2.04 \%$. The areas encompassing rural construction lands increased from 18.4728 million $\mathrm{hm}^{2}$ in 2009 to 19.2003 million $\mathrm{hm}^{2}$ in 2016, with a total growth of $722,500 \mathrm{hm}^{2}$, an annual growth of $90,300 \mathrm{hm}^{2}$, and an annual growth rate of $0.55 \%$. During the process of rapid urbanization, rural populations have flooded into cities and become urban population. However, the rural construction land areas did not decrease due to the decrease in the rural population but showed an increasing trend instead. The "separation of people and lands, and the increased use of land for construction with people leaving" in rural areas, eventually led to the doubled increase in construction lands in urban and rural areas.

(2) From the perspective of space, rural construction land areas increased in most provinces of China from 2009 to 2016. Areas with moderate and severe growth were concentrated in the eastern coastal areas; the three northeastern provinces, the central region, and the western region were the areas exhibiting a slight growth of rural construction lands. The areas of rural construction lands in Shanghai, Chongqing, and Anhui increased slightly. In addition to those of Beijing, Shanghai, Tianjin, and Tibet, the number of rural permanent residents in most provinces decreased. The rural permanent resident population also decreased severely in Henan, Jiangsu, Sichuan, Shandong, Guizhou, Anhui, and Hubei. Additionally, the total reduction in rural permanent residents in the seven provinces accounted for $44.04 \%$ of the total reduction in the rural permanent population from 2009-2016.

(3) According to the decoupling model, the decoupling relationship between rural construction lands and rural permanent population changes from 2009 to 2016 showed four states: weak decoupling, negative expansion decoupling, strong negative decoupling, and weak negative decoupling. Rural construction land areas and the number of the rural permanent population exhibited a strong negative decoupling at the national scale. With the exception of Beijing and Shanghai, the other provinces followed a trend of uncoordinated development, among which the main type was strong negative decoupling.

(4) According to the coordination degree model, the coordination type between the rural construction land areas and the number of rural permanent residents was inconsistent at the national scale. In fact, from the provincial perspective, the rural construction land areas in most provinces of China were out of balance with the number of the rural permanent population, which was manifested by the decrease in the rural permanent population and the increase in construction lands. These areas included 25 provinces: Hebei, Shanxi, Inner Mongolia, Liaoning, Jilin, Heilongjiang, Jiangsu, Zhejiang, Anhui, Fujian, Jiangxi, 
Shandong, Henan, Hubei, Hunan, Guangdong, Guangxi, Hainan, Chongqing, Sichuan, Guizhou, Yunnan, Shaanxi, Gansu, and Ningxia. The conditions of Beijing and Xizang were relatively coordinated; those of Tianjin and Shanghai were basically coordinated; Xinjiang and Qinghai belonged to the reconciliation type.

(5) According to the comprehensive measurement model, the proportions of the permanent population and rural construction lands showed two relations: highly negative decoupling and moderate and weakly strong negative decoupling. The twelve provinces and autonomous regions of Heilongjiang, Guangxi, Jiangsu, Liaoning, Hunan, Hubei, Sichuan, Henan, Shaanxi, Guizhou, Jiangxi, and Inner Mongolia presented a high strong negative decoupling. The reduction in the rural permanent resident population was the main reason for the highly strong and negative decouplings between the rural population and the scale of construction lands in these provinces. Eleven provinces, including Hainan, Gansu, Fujian, Shanxi, Shandong, Ningxia, Yunnan, Zhejiang, Hebei, Jilin, and Guangdong, were uncoordinated with moderate-mild negative decoupling. The expansion of rural construction lands was the most important reason for the highly strong negative decoupling between the rural population and the scale of construction lands in these provinces.

Urbanization has transformed a large number of the rural population into urban residents and brought along significant social benefits. However, the lands used for rural construction did not decrease with the transfer of the rural population; in fact, between 2009 and 2016, 23 provinces had experienced the phenomenon of "increasing construction lands with people leaving," thus resulting in a significant waste of land resources. Indeed, the areas of rural construction lands and the number of the rural permanent population showed a serious imbalance.

Author Contributions: Conceptualization, X.Z. and W.S.; methodology, X.Z. and J.W.; formal analysis, J.W. and F.W.; investigation, X.Z., X.G. and L.L.; resources, X.Z. and W.S.; writing-original draft preparation, J.W., X.G., K.D. and D.Y.; writing-review and editing, J.W., F.W., W.S. and X.G.; supervision, X.Z. and W.S. All authors have read and agreed to the published version of the manuscript.

Funding: This research was funded by Hebei Social Science Fund (HB19GL043).

Institutional Review Board Statement: Not applicable.

Informed Consent Statement: Not applicable.

Data Availability Statement: All relevant data sets in this study are described in the manuscript.

Conflicts of Interest: The authors declare no conflict of interest.

\section{References}

1. Nations, U. World Urbanization Prospects the 2018 Revision. Available online: https:/ / population.un.org/wup/Publications / Files/WUP2018-Report.pdf (accessed on 20 April 2021).

2. Available online: http:/ / www.stats.gov.cn/ (accessed on 1 April 2019).

3. Selod, H.; Shilpi, F. Rural-urban migration in developing countries: Lessons from the literature. Reg. Sci. Urban Econ. 2021, 91, 103713. [CrossRef]

4. Zhu, J.; Zhu, M.; Xiao, Y. Urbanization for rural development: Spatial paradigm shifts toward inclusive urban-rural integrated development in China. J. Rural. Stud. 2019, 71, 94-103. [CrossRef]

5. Zhu, C.; Zhang, X.; Wang, K.; Yuan, S.; Yang, L.; Skitmore, M. Urban-rural construction land transition and its coupling relationship with population flow in China's urban agglomeration region. Cities 2020, 101, 102701. [CrossRef]

6. Yanbo, Q.; Guanghui, J.; Yaya, T.; Shang, R.; Shuwen, W.; Yuling, L. Urban-Rural construction land Transition(URCLT) in Shandong Province of China: Features measurement and mechanism exploration. Habitat Int. 2019, 86, 101-115. [CrossRef]

7. Song, W.; Pijanowski, B.C. The effects of China's cultivated land balance program on potential land productivity at a national scale. Appl. Geogr. 2014, 46, 158-170. [CrossRef]

8. Zhang, Y.; Li, X.; Song, W. Determinants of cropland abandonment at the parcel, household and village levels in mountain areas of China: A multi-level analysis. Land Use Policy 2014, 41, 186-192. [CrossRef]

9. Song, W.; Deng, X. Land-use/land-cover change and ecosystem service provision in China. Sci. Total Environ. 2017, 576, 705-719. [CrossRef]

10. Liu, Y.W.L.; Long, H. Spatio-temporal analysis of land-use conversion in the Eastern Coastal China during 1996-2005. J. Geogr. Sci. 2008, 18, 274-282. [CrossRef] 
11. Wang, D.; Zhu, Y.; Zhao, M.; Lv, Q. Multi-dimensional hollowing characteristics of traditional villages and its influence mechanism based on the micro-scale: A case study of Dongcun Village in Suzhou, China. Land Use Policy 2021, 101, 105146. [CrossRef]

12. Wang, J.; Fang, C.L.; Li, Y.R. Spatio-temporal Analysis of Population and Construction Land Change in Urban and Rural China. J. Nat. Resour. 2014, 29, 1271-1281.

13. Long, H.; Li, Y.; Liu, Y.; Woods, M.; Zou, J. Accelerated restructuring in rural China fueled by 'increasing vs. decreasing balance' land-use policy for dealing with hollowed villages. Land Use Policy 2012, 29, 11-22. [CrossRef]

14. LIU Yansui, Y.R.; LI, Y. Potential of land consolidation of hollowed villages under different urbanization scenarios in China. J. Geogr. Sci. 2013, 23, 503-512.

15. Liu, Z. Human capital externalities and rural-urban migration: Evidence from rural China. China Econ. Rev. 2008, 19, 521-535. [CrossRef]

16. Wang, H.; Wang, L.; Su, F.; Tao, R. Rural residential properties in China: Land use patterns, efficiency and prospects for reform Habitat Int. 2012, 36, 201-209. [CrossRef]

17. Ye, J. Stayers in China's "hollowed-out" villages: A counter narrative on massive rural-urban migration. Popul. Space Place 2018, 24, e2128. [CrossRef]

18. Li, C.; $\mathrm{Wu}, \mathrm{K}$. Driving forces of the villages hollowing based on geographically weighted regression model: A case study of Longde County, the Ningxia Hui Autonomous Region, China. Nat. Hazards 2017, 89, 1059-1079. [CrossRef]

19. Lee, J.; Suh, K. A new index to assess vulnerability to regional shrinkage (Hollowing out) due to the changing age structure and population density. Sustainability 2021, 13, 9382. [CrossRef]

20. Zhang, R.; Jiang, G.; Zhang, Q. Does urbanization always lead to rural hollowing? Assessing the spatio-temporal variations in this relationship at the county level in China 2000-2015. J. Clean. Prod. 2019, 220, 9-22. [CrossRef]

21. Yin, K.; Wen, M.; Zhang, F.; Yuan, C.; Chen, Q.; Zhang, X. Research on the evaluation method of rural hollowing based on RS and GIS technology: A case study of the Ningxia Hui autonomous region in China. In Earth Resources and Environmental Remote Sensing/GIS Applications; SPIE: Washington, DC, USA, 2016; Volume 10005.

22. Gao, W.; de Vries, W.T.; Zhao, Q. Understanding rural resettlement paths under the increasing versus decreasing balance land use policy in China. Land Use Policy 2021, 103, 105325. [CrossRef]

23. Li, J.; Lo, K.; Zhang, P.; Guo, M. Reclaiming small to fill large: A novel approach to rural residential land consolidation in China. Land Use Policy 2021, 109, 105706. [CrossRef]

24. Huang, Q.; Song, W.; Song, C. Consolidating the layout of rural settlements using system dynamics and the multi-agent system. J. Clean. Prod. 2020, 274, 123150. [CrossRef]

25. Liu, Y.; Liu, Y.; Chen, Y.; Long, H. The process and driving forces of rural hollowing in China under rapid urbanization. J. Geogr. Sci. 2010, 20, 876-888. [CrossRef]

26. Delfmann, H.; Koster, S.; McCann, P.; Van Dijk, J. Population Change and New Firm Formation in Urban and Rural Regions. Reg. Stud. 2014, 48, 1034-1050. [CrossRef]

27. Yu, L.J.; Sun, D.S.; Zhang, D.X.; Zheng, B.; Han, L.; Yu, Z. Rural Household Survey Based Analysis of Hollowing of Rural Residential Land in China. Sci. Geogr. Sin. 2016, 36, 1043-1049.

28. Li, Y.; Liu, Y.; Long, H.; Cui, W. Community-based rural residential land consolidation and allocation can help to revitalize hollowed villages in traditional agricultural areas of China: Evidence from Dancheng County, Henan Province. Land Use Policy 2014, 39, 188-198. [CrossRef]

29. Song, Y.; Sun, J.; Zhang, M.; Su, B. Using the Tapio-Z decoupling model to evaluate the decoupling status of China's CO2 emissions at provincial level and its dynamic trend. Struct. Chang. Econ. Dynam. 2020, 52, 120-129. [CrossRef]

30. Wang, Q.; Su, M. Drivers of decoupling economic growth from carbon emission an empirical analysis of 192 countries using decoupling model and decomposition method. Environ. Impact Assess. Rev. 2020, 81. [CrossRef]

31. $\mathrm{Wu}, \mathrm{Y}$; Zhu, Q.; Zhu, B. Decoupling analysis of world economic growth and CO2 emissions: A study comparing developed and developing countries. J. Clean. Prod. 2018, 190, 94-103. [CrossRef]

32. Qian, Z. Master plan, plan adjustment and urban development reality under China's market transition: A case study of Nanjing. Cities 2013, 30, 77-88. [CrossRef]

33. Shen, J.; Lin, L. State-sponsored and spontaneous urbanization in Fujian province of China, 1982-2010. Cities 2017, 60, 420-427. [CrossRef]

34. Liu, Z.; Liu, S.; Jin, H.; Qi, W. Rural population change in China: Spatial differences, driving forces and policy implications. J. Rural. Stud. 2017, 51, 189-197. [CrossRef]

35. Qi, W.; Deng, Y.; Fu, B. Rural attraction: The spatial pattern and driving factors of China's rural in-migration. J. Rural. Stud. 2019. [CrossRef]

36. Busso, M.; Chauvin, J.P.; Herrera, L.N. Rural-urban migration at high urbanization levels. Reg. Sci. Urban Econ. $2021,91,103658$. [CrossRef]

37. Laing, D.; Park, C.; Wang, P. A modified Harris-Todaro model of rural-urban migration for China. In Critical Issues in China's Growth and Development; Taylor \& Francis Group: London, UK, 2005; pp. 245-264.

38. Bairoliya, N.; Miller, R. Social insurance, demographics, and rural-urban migration in China. Reg. Sci. Urban Econ. 2021, 91, 103615. [CrossRef] 
39. Gu, H.; Ling, Y.; Shen, T.; Yang, L. How does rural homestead influence the hukou transfer intention of rural-urban migrants in China? Habitat Int. 2020, 105, 102267. [CrossRef]

40. Liu, T.; Wang, J. Bringing city size in understanding the permanent settlement intention of rural-urban migrants in China. Popul. Space Place 2020, 26. [CrossRef]

41. Zhu, N. The impacts of income gaps on migration decisions in China. China Econ. Rev. 2002, 13, 213-230. [CrossRef]

42. Su, Y.; Tesfazion, P.; Zhao, Z. Where are the migrants from? Inter- vs. intra-provincial rural-urban migration in China. China Econ. Rev. 2018, 47, 142-155. [CrossRef]

43. Qu, Y.; Zhan, L.; Jiang, G.; Ma, W.; Dong, X. How to Address "Population Decline and Land Expansion (PDLE)" of rural residential areas in the process of Urbanization:A comparative regional analysis of human-land interaction in Shandong Province. Habitat Int. 2021, 117, 102441. [CrossRef]

44. China National Knowledge Infrastructure(CNKI). China Economic and Social Big Data Research Platform. Available online: https:/ / data.cnki.net/ (accessed on 1 August 2020).

45. Land Survey Results Sharing Application Service Platform. Data of Rural Construction Land Area. Available online: https: / / data.stats.gov.cn/ (accessed on 1 October 2021).

46. Tapio, P. Towards a theory of decoupling: Degrees of decoupling in the EU and the case of road traffic in Finland between 1970 and 2001. Transp. Policy 2005, 12, 137-151. [CrossRef]

47. Zhongmin, L.; yaohua, S. Analysing on the Decoupling Relationship Between Carbon Dioxide Emissions and Economic Growth of Each Province in China. China Popul. Resour. Environ. 2005, 12, 87-92.

48. Sun, Y.; Wang, N. Development and correlations of the industrial ecology in China's Loess Plateau: A study based on the coupling coordination model and spatial network effect. Ecol. Indic. 2021, 132, 108332. [CrossRef]

49. Yan Xuyang, T.L.Y.Y. Functional Reconstruction of Hollow Village from the Perspective of Urban-Rural Relations: Dynamics and Mechanism_-A Case Study of the "Rebirth" of Ganyugou Village. Manag. Rev. 2020, 32, 325-336.

50. Sun, H.; Liu, Y.; Xu, K. Hollow villages and rural restructuring in major rural regions of China: A case study of Yucheng City, Shandong Province. Chin. Geogr. Sci. 2011, 21, 354-363. [CrossRef]

51. Stockdale, A. Contemporary and 'Messy' Rural In-migration Processes: Comparing Counterurban and Lateral Rural Migration: Research on Lateral Rural Migration. Popul. Space Place 2015, 22, 599-616. [CrossRef]

52. Ge, D.; Long, H.; Qiao, W.; Wang, Z.; Sun, D.; Yang, R. Effects of rural-urban migration on agricultural transformation: A case of Yucheng City, China. J. Rural. Stud. 2020, 76, 85-95. [CrossRef]

53. Guo, Y.; Qiao, W. Rural Migration and Urbanization in China: Historical Evolution and Coupling Pattern. Sustainability 2020, 12, 7307. [CrossRef] 